\title{
ОЦІНКА ЗЕМЕЛЬ
}

UDC: 911.9:(332.6+71)

\section{POPULATION SIZE AS A FACTOR FOR FORMATION OF LAND VALUE IN SETTLEMENTS}

Kovalchuk I., Doctor of Geography, Professor,

National University of Life and Environmental Sciences of Ukraine,

E-mail: kovalchukip@ukr.net

Patychenko O., Stuff Scientist at the State Enterprise Y. Bilokon Ukrainian State Scientific-Research Institute of Urban Design "DIPROMISTO",

E-mail: 12122014@ukr.net

Paper reflects on the features of the formation of normative monetary evaluation of land in settlements (hereinafter abbreviated as NME).

The nature of the formation of the constituent of the regional differential land rent coefficient Km1 - the coefficient characterizing population size (Km1p). Ukraine settlements classifications scheme suggested, which gives a comprehensive imagination of urban and rural settlements hierarchy in the general resettlement system of the state. Influence of indicators of a population size of different categories on a residence place - the available and permanent population on NME value is analyzed. The desirability of making changes to the Order of normative monetary evaluation of land in settlements has been justified. Specifically, it is proposed to point out that the calculation of NME is based on the account of the constant population size at the beginning of the year for which normative monetary evaluation of land is being performed.

Keywords. Land management, urban development, normative monetary evaluation of land in settlements (NME), population.

\section{Formulation of the problem.}

Urban and land management in Ukraine is intended to ensure sustainable development at national, regional and local levels

The establishment of payment for land is one of the levers of territory rational use. In Ukraine payment for land established on the land normative monetary evaluation base. Feature of land valuation in Ukraine are different methodological approaches to the assessment of different categories of land. There are the following categories of normative monetary evaluation: monetary evaluation of settlements lands, non-agricultural lands assessment (ex- 
cept settlements lands) and agricultural lands assessment. Areas of application of land valuation are regulated by legislative and regulatory documents.

This article is devoted to the issues of normative monetary evaluation of settlements lands (hereinafter abbreviated as NME).

A legislative basis of the NME implementation is set out in article 201 of the Land code of Ukraine, in part XII of the Fiscal code of Ukraine, and in the Law of Ukraine "On land evaluation"; a normative-methodical basis of NME is the Method for monetary evaluation of land in settlements [1] (hereinafter-Method) and the Procedure for normative monetary evaluation of land in settlements [2] (hereinafter - Procedure). The main problem of NME calculation is that since the approval of the Method and Procedure, amendments and additions have been made to them many times, but their essence has not changed since 1995 and does not correspond to reality. Separate indicators of differential land rent formation need to be clarified.

The issues of land evaluation are devoted to such scientific works of Ukrainian and foreign scientists as $\mathrm{N}$. Komova, P. Loiko, V. Kilochko, A. Martin [3 - 6]. Settlements lands normative monetary evaluation features are most broadly highlighted in the works of Y. Dehtiarenko, M. Lykhohrud, Y. Mantsevych, Y. Palekha [7 - 10]. Yet the issue of the influence of the settlement population size indicators on the land value in these settlements remained unnoticed.

\section{The purpose of this article.}

The aim of this article is to study the features of influence of available and permanent population size on the value of normative monetary evaluation of land in settlements.

\section{Presenting main material.}

According to the current methodology, depending on town (city) population, NME differentiates - increases from 1,2 to 3,00 times. [2, Appendix 2].

Population indicators for different categories of place of residence (for permanent and current population) have different meanings [11]. Uncertainty in the issue of establishing a payment for land on the basis of which particular category of the population at the place of residence can input an error in the calculation of the tax. In terms of the number of permanent or current residents of the city can be classified in different categories [2, Appendix 2], which will unjustly change their NME at times! In connection with the above, the research topic of this article is relevant and has practical application.

Normative monetary evaluation of land in settlements (NME), like the evaluation of other land categories is determined on rental basis and represents the capitalized rental income from a land parcel [1, 2, 10]; the calculation procedure is set out in the Method and Procedure [1, 2]. The general value of the land parcel in settlement is formed by the infrastructural and geographic constituents of differential land rent. The geographic constituent reflects on the convenience of location of land parcel, the infrastructural one - its arrangement level $[9,10,12]$. The geographic constituent of differential land rent reflects the formation of lands value in settlements on three levels: regional, intrasettlement and local, and is regulated by the value of $\mathrm{Km}$ coefficient [1, 2, 8 - 10]. One of the main factors forming the value of the $\mathrm{Km}$ coefficient is the coefficient characterizing the population size, geographical position, admin- 
istrative status of the settlement and its economic functions. In scientific work [13], it was suggested to assign this index to the index $\mathrm{KM} 1 \mathrm{H}$, and to describe the methodology for calculating the $\mathrm{Km}$ coefficient by the formula.

Let's analyze the essence of the coefficient that characterizes the population $-\mathrm{Km} 1 \mathrm{p}$.

Land normative monetary evaluation size is significantly different in various localities. In the table on the example of average NME indicators below [14] the range of values of monetary estimation for urban settlements of Ukraine is illustrated.
Such a difference in the monetary valuation of land is largely related to the hierarchical distribution of settlements in the general settlement system. The main indicators that characterize the place of a settlement in the settlement system are population size, administrative status, economic functions [8]. These characteristics are used as the basis for the classification of settlements, and in the NME differentiate their monetary value and are regulated by the value of the regional coefficient $\mathrm{Km} 1$ [2]. In the article below the scheme of belonging of settlements to different categories of groupings is given, which gives a complex idea of the

\section{$T a b$ - Average costs for the area development and accomplishment, $\mathrm{UAH} / 1 \mathrm{M}^{2}$, for Ukrainian settlements [14, p.64] (as of 01.01.2012)}

\begin{tabular}{|c|c|c|c|}
\hline $\begin{array}{l}\text { Groups of settlements with } \\
\text { population size (thousand } \\
\text { inhabitants) }\end{array}$ & $\begin{array}{l}\text { Urban settlements } \\
\text { (cities and towns) }\end{array}$ & Rural settlements & $\begin{array}{l}\text { Average by all } \\
\text { settlements }\end{array}$ \\
\hline Less 0,2 & 17,49 & 7,92 & 7,92 \\
\hline From 0,2 to 0,5 & & 11,01 & 11,33 \\
\hline From 0,5 to 1,0 & 12,83 & 10,77 & 11,40 \\
\hline From 1,0 to 5,0 & 17,39 & 11,99 & 13,88 \\
\hline From 5,0 to 10,0 & 21,51 & 14,46 & 18,34 \\
\hline From 10,0 to 20,0 & 25,15 & 11,96 & 21,19 \\
\hline From 20,0 to 50,0 & 32,45 & - & 32,45 \\
\hline From 50,0 to 100,0 & 33,83 & - & 33,83 \\
\hline From 100,0 to 250,0 & 38,87 & - & 38,87 \\
\hline From 250,0 to 500,0 & 44,27 & - & 44,27 \\
\hline $\begin{array}{l}\text { From } 500,0 \text { to } 1000,0 \text { and } \\
\text { Sevastopol city }\end{array}$ & $65,27 *$ & - & $65,27^{*}$ \\
\hline From 1000,0 to 2000,0 & 51,77 & - & 51,77 \\
\hline More 2000,0 & 64,30 & - & 64,30 \\
\hline
\end{tabular}


hierarchy of settlements in the general system of settlement of Ukraine.

In the statistical studies of the Ukrainian demographic situation the population size categories are discerned based on the place of residence $[15, \mathrm{p}$. 1]: permanent population, present and legal population. During population cen-

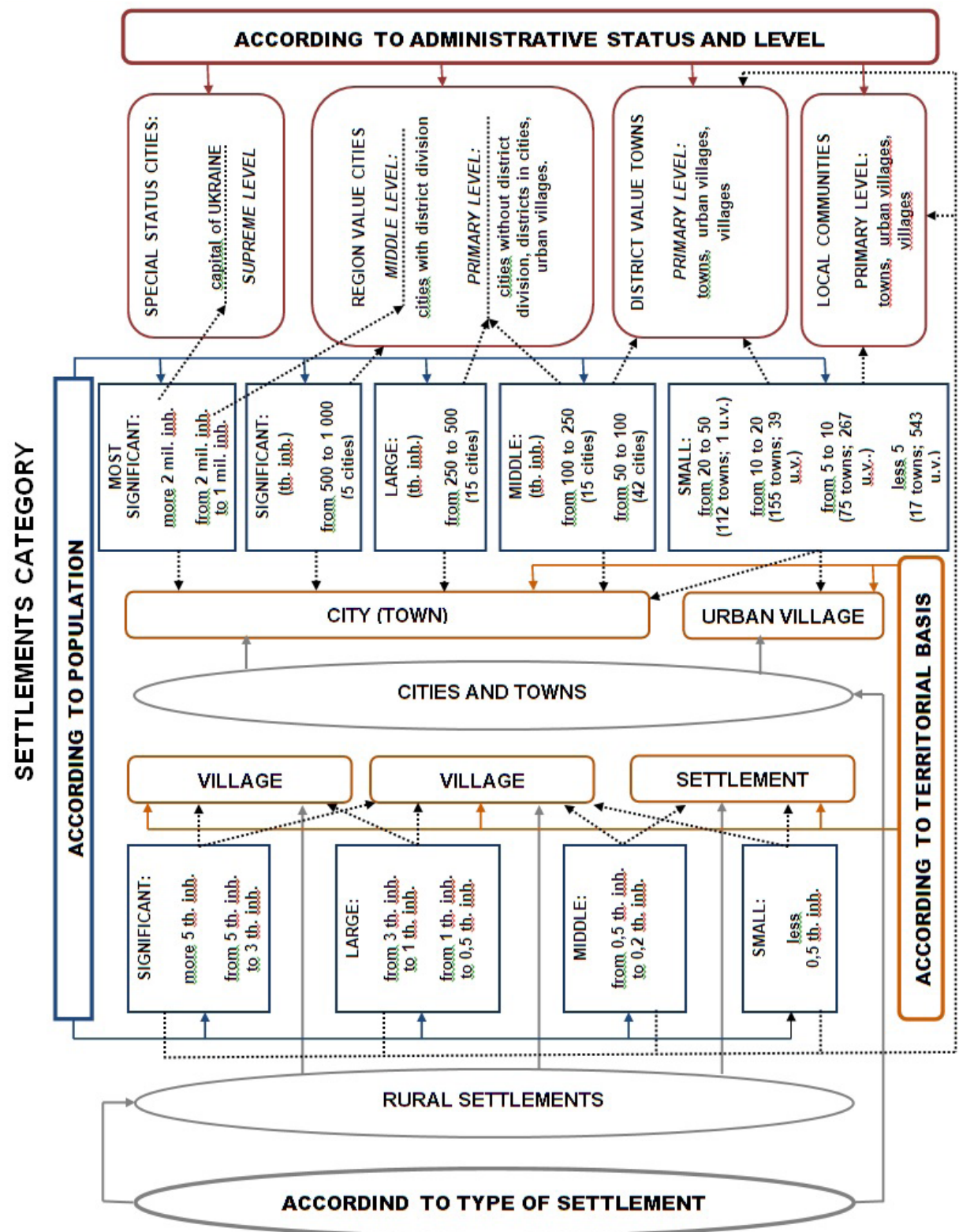

Note - in the classification by population, the number of urban settlements are shown as of 01/01/2017. Excluding Crimea; rural settlements are not calculated.

Figure- Ukraine settlements categories classifications scheme 
suses in Ukraine first two categories are being accounted for. In item 2.1 of Methodical regulations on statistical analysis of population count and structure it is noted that: «Present population is the number of persons that at the time of registration stay at the area of a certain settlement, independent of the place of their permanent residence. Present population of a given area consists of people that stay there at the time of the census irrespective of the duration of their stay, whether they are about to leave it or not, whether or not are they recorded in lists. Permanent population is the number of persons that permanently, during a significant time span live in the area of certain settlement, irrespective of whether they are staying there at the time of the census. Permanent population consists of persons that permanently dwell in given place, irrespective of whether they are there at any given moment and whether the records of them exist in any lists of inhabitants.» [15].

The purpose of NME is to determine the value of a certain land parcel in settlement (Vn) [2, items 3]. On the basis of NME the cost of land parcel usage is imposed for parcels that are owned or rented. The level of land values in settlements reflects their level of urban development. Urban development features of settlement form during all its history by its inhabitants, which create its industrial, social and infrastructural potential and form the absolute majority of owners and tenants of land parcels.

Thus, population size as one of the major indices of the formation of the land value of settlement on a regional level, should take into account a permanent population. Currently, Procedure [2, items 7, 2, Appendix 2] doesn't indicate which category of population size by place of residence should be used to calculate the regional constituent $\mathrm{Km} 1 \mathrm{p}$ - permanent or present. In practice, the values of present population size are usually used. This approach could introduce a significant error in the calculation of the basic NME index - the average (basic) lands value (Vnl) [2, items 7]. The group of risk includes settlements that are in the number of available and permanent population size fall into different types of cities by administrative status and economic functions [2, items 7].

For instance, the membership to different settlement subgroups with the population size of $20.0-49.9$ thousand persons or 50,0 - 99,9 thousand persons changes the value of land parcel under the influence of the value of coefficient $\mathrm{K} \mathrm{m} 1 \mathrm{p}$ in 0.2 times; for settlement subgroups with population size of 250.0 - 499.9 thousand persons or 500.0 999.9 thousand persons - in 0.5 times!

Taking into account the foregoing and based on the studies carried out $[13,14]$ in Procedure in item 7 and in Supplement 2 it is appropriate to make notion that the calculation of NME is based on sizes of the permanent population at the beginning of the year when the normative monetary evaluation of land in settlement is accomplished.

\section{Conclusions.}

The absence in the Procedure for normative monetary evaluation of land in settlements population category emphasis by place of residence (permanent or present) needed to determine the coefficient $\mathrm{K} \mathrm{m} 1 \mathrm{p}$, leads to ambiguity - whether the size of the permanent or of the present population should be taken into account? This can lead to unfounded understatement or overstatement of the NME value 
when different values of population size are used. Since the majority of land parcel owners and tenants are the inhabitants of settlements, the number of which is conveyed by the value of permanent population size, and it is this category of population that creates urban infrastructure, this index should be used when evaluating the values of $\mathrm{Kmlp}$ coefficient. The Procedure for normative monetary evaluation of land in settlements (Attachement 2) should mention that the calculation of NME is based on the size of permanent population for the beginning of the year when the evaluation is carried out.

\section{References}

1. Metodyka hroshovoi otsinky zemel naselenykh punktiv (tymchasova) [Methodology of monetary valuation of settlements (temporal)]. Available at: http:// zakon2.rada.gov.ua/laws/show/213-95-п

2. Podatkovyi kodeks Ukrainy vid 02.12.2010 za №2755-VI [The Tax Code of Ukraine dated 02.12.2010 for №2755-VI]. Available at: http://zakon2.rada.gov.ua/laws/ show/2755-17

3. Komov, N.V., Arbatskii, D.B. (2000). Metodolohiia upravleniia zemelnymi resursami: ucheb. posobie. [Methodology of land management: a manual]. Nizhny Novgorod, Russia: Publishing house of the Volga-Vyatka Academy of Civil Service, 246.

4. Kilochko, V.M. (2004). Udoskonalennia hroshovoi otsinky zemel v Ukraini [Improvement of the monetary valuation of land in Ukraine]. Kyiv, Ukraine: LLC “CZRU”, 160.

5. Loiko, P.F. (2001). Sovremennoie mnohoukladnoie zemlepolzovaniie (nekotoryie aspekty teorii, mirovoi i otechestvennoi praktiki) [Modern multi-layered land use (some aspects of theory, world and domestic practice)]. Moskva, Russia: FC "Earth", UC “Earth”, 111.
6. Martyn, A. H. (2013). Novyi metodychnyi pidkhid do normatyvnoi hroshovoi otsinky zemel nesilskohospodarskoho pryznachennia [A new methodological approach to normative monetary valuation of non-agricultural land]. Land management and cadaster, 2, 37-59. Available at: http://nbuv. gov.ua/UJRN/Zik_2013_2_7

7. Borzdova, T.V. (2015). Kadastrovaia otsenka zemel naselennykh punktov: tseli i poriadok provedeniia $v$ respublike Belarus [Cadastral assessment of settlements' lands: goals and procedure for carrying out in the Republic of Belarus]. The Bulletin of the Customs Academy of Ukraine. Series: "Economics", 2 (54), 13-23.

8. Dekhtiarenko, Iu. F., Lykhohrud, M. H., Mantsevych, lu. M., Palekha, lu. M. (2007). Metodychni osnovy hroshovoi otsinky zemel v Ukraini [Methodological foundations of the monetary valuation of land in Ukraine]. Kyiv, Ukraine: Profi. 624.

9. Palekha, Iu. N. (2002). Heohraficheskiie osobennosti formyrovaniia rehyonalnoi zemelnoi renty $v$ horodakh Ukrainy [Geographical features of the formation of regional land rent in the cities of Ukraine]. Scientific notes of the Taurian National University. V.V. Vernadsky. Geography, 15(54), 57-62.

10. Palekha, Iu.M., Kolosiuk, A.A. (2013) Normatyvna hroshova otsinka zemel naselenykh punktiv: na rubykoni zmin [Normative monetary valuation of settlements: on the rubicon of changes]. Land management and cadaster, 1, 60-67.

11. Pro zatverdzhennia Metodolohichnykh polozhen shchodo statystychnoho analizu chyselnosti ta skladu naselennia Zakony Ukrainy [On Approval of Methodological Provisions on Statistical Analysis of Population and Population. Laws of Ukraine]. Available at: http://uazakon.com/documents/date_ci/pg_gbntwo/index.htm

12. Stupen, M. H. ed. (2014). Otsinka zemel [Land valuation]. Kyiv, Ukraine: AgroUniversity, 373. 
13. Palekha, lu.M. (2009). Teoriia i praktyka vyznachennia vartosti terytorii i otsinky zemel naselenykh punktiv Ukrainy [Theory and practice of determination of the value of territories and estimation of lands of settlements of Ukraine]. Kyiv, Ukraine, 425.

14. Palekha, lu. M. (2006). Ekonomiko-heohrafichni aspekty formuvannia vartosti terytorii naselenykh punktiv [Economic-geographical aspects of formation of the cost of territories of settlements] .Kyiv, Ukraine: Profi, 324.

15. Poriadok normatyvnoi hroshovoi otsinky zemel naselenykh punktiv. Nakaz Minahropolityky Ukrainy [The procedure for normative monetary valuation of settlements' land]. - Available at: http://zakon5.rada. gov.ua/laws/show/z1647-16/page

$* * *$

КовальчУк І.П., Патиченко О.М. ЧИСЕЛЬНІСТЬ НАСЕЛЕННЯ ЯК ЧИННИК ФОРМУВАННЯ НОРМАТИВНОЇ ГРОШОВОЇ ОЦІНКИ ЗЕМЕЛЬ НАСЕЛЕНИХ пунктІв.

у статті висвітлено особливості формування нормативної грошової оцінки земель населених пунктів (далі скорочено нго).

Проаналізована природа формування складової регіонального коефіцієнта диреренціальної земельної ренти КМ1, який характеризує чисельність населення (КМ1Н). Запропонована схема класифікації населених пунктів України, яка дає комплексну уяву про ієрархію міських та сільських населених пунктів у загальній системі розселення держави. здійснена оцінка впливу показників чисельності населення різних категорій за місцем проживання (наявного та постійного) на величину НГО. Обгрунтовано доцільність внесення змін до Порядку нормативної грошової оцінки земель населених пунктів. зокрема, запропоновано вказувати, що розрахунок НГО базується на врахуванні чисельності постійного населення на початок року, в якому виконується грошова оцінка земель населеного пункту.

Ключові слова: землеустрій, містобудування, нормативна грошова оцінка земель населених пунктів (НГО), чисельність населення.

Ковальчук И.П., Патыченко О.Н. ЧИСЛЕННОСТЬ НАСЕЛЕНИЯ КАК ФАКТОР ФОРМИРОВАНИЯ НОРМАТИВНОЙ ДЕНЕЖНОЙ ОЦЕНКИ ЗЕМЕЛЬ НАСЕЛЕННЫХ ПУНКТОВ

В статье освещены особенности формирования нормативной денежной оценки земель населенных пунктов (далее сокращенно - НДО).

Проанализирована природа формирования составляющей регионального коэффиициента дифрференциальной земельной ренты KM1, характеризующего численность населения (КМ1Н). Предложена схема классификации населенных пунктов Украины, которая дает комплексное представление об иерархии городских и сельских населенных пунктов в общей системе расселения населения в государстве. Осуществлена оценка влияния показателей численности населения разных категорий по месту жительства (наличного и постоянного) на величину НДО. Обоснована челесообразность внесения изменений в Порядок нормативной денежной оценки земель населенных пунктов. В частности, предложено указывать, что расчет НДО базируется на учете численности постоянного населения на начало года, в котором выполняется денежная оценка земель населенного пункта.

Ключевые слова: землеустройство, градостроительство, нормативная денежная оценка земель населенных пунктов (НДО), численность населения. 